\title{
Purpose of Livestock Rearing and Economic Benefit Gained by the Farmers of Indo-Bangladesh Border Areas of Dhubri District of Assam, India
}

\author{
Liakot Hussain $^{1 *}$, K.K. Saharia ${ }^{1}$, L. Bora ${ }^{1}$, I.U. Sheikh ${ }^{2}$, D.C. Mili ${ }^{3}$, \\ Sanghamitra Kalita ${ }^{4}$ and S. Payeng ${ }^{1}$ \\ ${ }^{1}$ Department of Extension Education, College of Veterinary Science, Assam Agricultural \\ University, Khanapara, Guwahati-781022, India \\ ${ }^{2}$ F.V.Sc \& A.H, SKUAST-Kashmir, Shuhama, India \\ ${ }^{3}$ Department of Livestock Production and Management, CVSc, AAU, Khanapara, India \\ ${ }^{4}$ Department of Poultry Science, CVSc, AAU, Khanapara, India \\ *Corresponding author
}

\section{A B S T R A C T}

\begin{tabular}{|l|}
\hline K e y w o r d s \\
Border areas, Purpose, \\
Livestock rearing, \\
Economic benefit \\
\hline Article Info \\
\hline $\begin{array}{l}\text { Accepted: } \\
\text { 04 May } 2018 \\
\text { Available Online: } \\
\text { 10 June } 2018\end{array}$ \\
\hline
\end{tabular}

The study was conducted in the Indo-Bangladesh border areas of South SalmaraMankachar Sub-Division of Dhubri District, Assam with a two phased data collection procedure to know the purpose of rearing livestock by the farmers. A pre-tested, reliable and valid interview schedule was used for data collection. Data were collected by the researcher personally. After data analysis, it was found that majority of the respondents' livestock rearing purposes were for economic purposes followed by agricultural purpose and for own consumption of produces. It was found that highest number of respondents (8.89 per cent) reared livestock to be sold at maturity while followed by use of agricultural purposes mainly for draft and manure (7.52 per cent) and personal consumption of milk /egg etc. (7.39 per cent). A maximum of Rs. 30,000/- per year was obtained by the farmers from buffaloes against lifetime expenditure Rs. 1,500/per animal while in cattle it was Rs. 4,000/- per head per year against lifetime expenditure Rs. 1,200/- per animal.

\section{Introduction}

Contribution of livestock sector in India has provided sustainability and stability to the national economy. It has its own strength. In contrast to the agricultural sector, particularly the Livestock sector not only provides essential proteins and nutritious human diet through milk, egg, meat etc. but livestock also provides raw materials and byproducts such as hides and skins, blood, bone, fat etc. which have huge economic importance. The livestock owners consider many factors before choosing a particular type of animal for rearing. The factors may include profitability in the enterprise, culture, climatic condition and availability of feeds and fodder in the locality. The people of the Indo-Bangladesh border areas are exposed to a different situation and factors in comparison to their counterparts in the main land areas. Therefore a study with the objectives of determining the 
purpose of animal rearing and economic gained by the livestock farmers in IndoBangladesh border areas was considered worthwhile.

\section{Materials and Methods}

The study was conducted in the IndoBangladesh border areas of South SalmaraMankachar Sub-division of Dhubri District of Assam. Out of the total fifteen villages which adjacent to Indo-Bangladesh International Border areas of the Sub Division, three villages were chosen randomly from the list. A further list of all the farmers having at least one cattle/buffalo in those selected village was prepared separately. Finally, thirty six such farmers were selected from each of the three villages making the sample size of 108. Data were personally collected by the researchers. Purpose of rearing livestock was measured by a specially prepared check list containing as many as 24 options of purposes.

The respondents were asked to respond to the different purposes placed before them in either of the three degrees ranging from mostly, sometimes to occasionally with their respective weights of 3,2 and 1 . As such the total obtainable score against this variable ranged from zero to 72 were taken. The economic benefits obtained by the farmers from livestock were ascertained by direct questioning. The reliability co-efficient of the check list was worked out by placing the schedule to a batch of subjects in non-sample area. The test retest method yielded a " $r$ " value of 0.92 indicating the fact that the check list was quite reliable.

The validity of the check list was obtained by adopting the criteria where the sensitive manner of selection of the purposes was given top priority and all the items selected for the purpose contained nothing else that the reasons behind rearing of the livestock.

\section{Results and Discussion}

The perusal of Table 1 revealed that highest number of respondents 8.89 per cent reared livestock to be sold at maturity while followed by use of agricultural purposes mainly for draft and manure (7.52 per cent) and personal consumption of milk/egg/beef etc. (7.39 per cent). In the fourth, fifth and sixth ranks were "to get some additional income and meet the domestic expenditure" (7.11 per cent), "for special occasion/festival and rituals" (6.70 per cent) and "to act as an insurance against any unfortunate happening" (5.68 per cent) respectively.

The least preferred three purposes were "to provide engagement to the educated unemployed ward/son/daughter" (2.94 per cent) with $21^{\text {st }}$ rank, "as hobby" (2.53 per cent) with $22^{\text {nd }}$ rank and "for purchase of household items whenever needed by selling the livestock" (1.09 per cent) with $23^{\text {rd }}$ rank.

Majority of the respondents' livestock rearing purposes were for economic purpose followed by agricultural purpose and for own consumption of produces including use of byproducts in the field. The order of preferences also included to get additional income and meet the domestic expenditure, for special occasion/festivals and rituals, to act as insurance for family member, influenced by other, followed by proper utilization of extra time, for getting easy loans from financial agencies, followed by for getting social pride and prestige etc.

These findings were more or less similar with Bujarbaruah et al., (1995) who found animal husbandry as the best alternative source of livelihood. Devendra and Chantalakhana (2002) stated that livestock were valuable for agriculture and farm security, milk and beef, ploughing and dung production and for nutritional and household security. 
Table.1 Distribution of respondents based on different purposes of rearing livestock

\begin{tabular}{|l|l|l|l|l|}
\hline $\begin{array}{l}\text { Sl. } \\
\text { No }\end{array}$ & Purpose & Frequency & Percentage & Ranked \\
\hline 1. & To use for agricultural purposes mainly for draft and manure & 110 & 7.52 & $\mathbf{2}^{\text {nd }}$ \\
\hline 2. & Personal consumption of milk/egg/beef etc. & 108 & 7.39 & $\mathbf{3}^{\text {rd }}$ \\
\hline 3. & $\begin{array}{l}\text { To get some additional income and meet the domestic } \\
\text { expenditure }\end{array}$ & 104 & 7.11 & $4^{\text {th }}$ \\
\hline 4. & For selling at maturity & 130 & 8.89 & $\mathbf{1}^{\text {st }}$ \\
\hline 5. & For special occasion/festivals and rituals & 98 & 6.70 & $5^{\text {th }}$ \\
\hline 6. & Because of getting Govt. patronage & 53 & 3.63 & $11^{\text {th }}$ \\
\hline 7. & For getting easy loans from financial agencies & 59 & 4.04 & $9^{\text {th }}$ \\
\hline 8. & For family members pressing it & 44 & 3.01 & $19^{\text {th }}$ \\
\hline 9. & Because others are also doing and benefiting & 73 & 5.00 & $7^{\text {th }}$ \\
\hline 10. & For getting social pride and prestige & 55 & 3.76 & $10^{\text {th }}$ \\
\hline 11. & For image building & 45 & 3.08 & $17.5^{\text {th }}$ \\
\hline 12. & In order to draw public sympathy & 52 & 3.56 & $12^{\text {th }}$ \\
\hline 13. & For proper utilization of extra time & 71 & 4.86 & $8^{\text {th }}$ \\
\hline 14. & For proper utilization of kitchen waste & 47 & 3.21 & $16^{\text {th }}$ \\
\hline 15. & For keeping the health of the family members well & 49 & 3.35 & $14^{\text {th }}$ \\
\hline 16. & To keep the unwanted growth of herbs and weeds under control & 42 & 2.87 & $20^{\text {th }}$ \\
\hline 17. & For getting some fun/solace/satisfaction & 48 & 3.28 & $15^{\text {th }}$ \\
\hline 18. & $\begin{array}{l}\text { For purchase of household items whenever needed by selling } \\
\text { the livestock }\end{array}$ & 16 & 1.09 & $23^{\text {rd }}$ \\
\hline 19. & $\begin{array}{l}\text { To provide engagement to the educated unemployed } \\
\text { ward/son/daughter }\end{array}$ & 43 & 2.94 & $21^{\text {st }}$ \\
\hline 20. & To act as an insurance against any unfortunate happening & 83 & 5.68 & 6 th \\
\hline 21. & To keep members of the family engaged & 45 & 3.08 & $17.5^{\text {th }}$ \\
\hline 22. & To set a good example of work cultures to the followers & 50 & 3.42 & $13^{\text {th }}$ \\
\hline 23. & As hobby & 37 & 2.53 & $22^{\text {nd }}$ \\
\hline & Total & & 100.00 & \\
\hline
\end{tabular}

\begin{tabular}{|l|l|r|r|r|r|}
\hline \multicolumn{5}{|c|}{ Table.2 A verage economic benefit from different livestock per year } \\
$\begin{array}{l}\text { S1. } \\
\text { No. }\end{array}$ & Type of livestock & $\begin{array}{r}\text { Total } \\
\text { Management } \\
\text { cost/unit (Rs.) }\end{array}$ & $\begin{array}{c}\text { Total } \\
\text { income/unit } \\
\text { (Rs.) }\end{array}$ & $\begin{array}{c}\text { Average } \\
\text { duration of } \\
\text { rearing (Year) }\end{array}$ & $\begin{array}{c}\text { A verage yearly } \\
\text { income/unit } \\
\text { (Rs.) }\end{array}$ \\
\hline 1. & Cattle & $1,200 /-$ & $24,000 /-$ & 6 & $4,000 /-$ \\
\hline 2. & Buffalo & $1,500 /-$ & $1,80,000 /-$ & 6 & $30,000 /-$ \\
\hline 3. & Sheep & $400 /-$ & $6,000 /-$ & 8 & $1,000 /-$ \\
\hline 4. & Goat & $400 /-$ & $7,000 /-$ & 7 & $1,000 /-$ \\
\hline 5. & Poultry chicken & $100 /-$ & $600 /-$ & 2 & $300 /-$ \\
\hline 6. & Poultry Duck & $80 /-$ & $600 /-$ & 2 & $300 /-$ \\
\hline
\end{tabular}




\begin{tabular}{|c|c|c|c|c|c|c|c|}
\hline $\begin{array}{l}\text { SI. } \\
\text { No. }\end{array}$ & Traits & Mean & $\begin{array}{l}\text { Standard } \\
\text { Deviation }\end{array}$ & Range & Low & Medium & High \\
\hline 1. & Family income & 110972.2 & 69369.18 & $\begin{array}{l}24000- \\
500000\end{array}$ & $\begin{array}{c}9(8.3) \\
\leq 41603\end{array}$ & $\begin{array}{c}84(77.78) \\
42000- \\
179000\end{array}$ & $\begin{array}{l}15(13.89) \\
\geq 180341\end{array}$ \\
\hline 2. & Income (A.H) & 18740.74 & 2865.77 & $\begin{array}{c}1500- \\
270000\end{array}$ & $\begin{array}{c}70(64.81) \\
\leq 15874\end{array}$ & $\begin{array}{c}16(14.81) \\
15873- \\
21605\end{array}$ & $\begin{array}{c}22(20.39) \\
\geq 21606\end{array}$ \\
\hline 3. & Own income & 94017.59 & 69981.85 & $\begin{array}{l}15000- \\
460000\end{array}$ & $\begin{array}{l}3(2.78) \\
\leq 24035\end{array}$ & $\begin{array}{c}91(84.26) \\
24034- \\
163998\end{array}$ & $\begin{array}{l}14(12.96) \\
\geq 163999\end{array}$ \\
\hline 4. & Livestock unit & 4.40 & 2.43 & $1-15$ & $\begin{array}{c}12(11.11) \\
\leq 1.97\end{array}$ & $\begin{array}{l}83(76.85) \\
1.98-6.82\end{array}$ & $\begin{array}{c}13(25.12 .04) \\
\geq 6.83\end{array}$ \\
\hline 5. & $\begin{array}{l}\text { Purpose of } \\
\text { rearing }\end{array}$ & 21.7 & 6.84 & $9-39$ & $\begin{array}{c}18(16.67) \\
\leq 14\end{array}$ & $\begin{array}{c}62(57.40) \\
15-27\end{array}$ & $\begin{array}{c}28(25.93) \\
\geq 28\end{array}$ \\
\hline
\end{tabular}

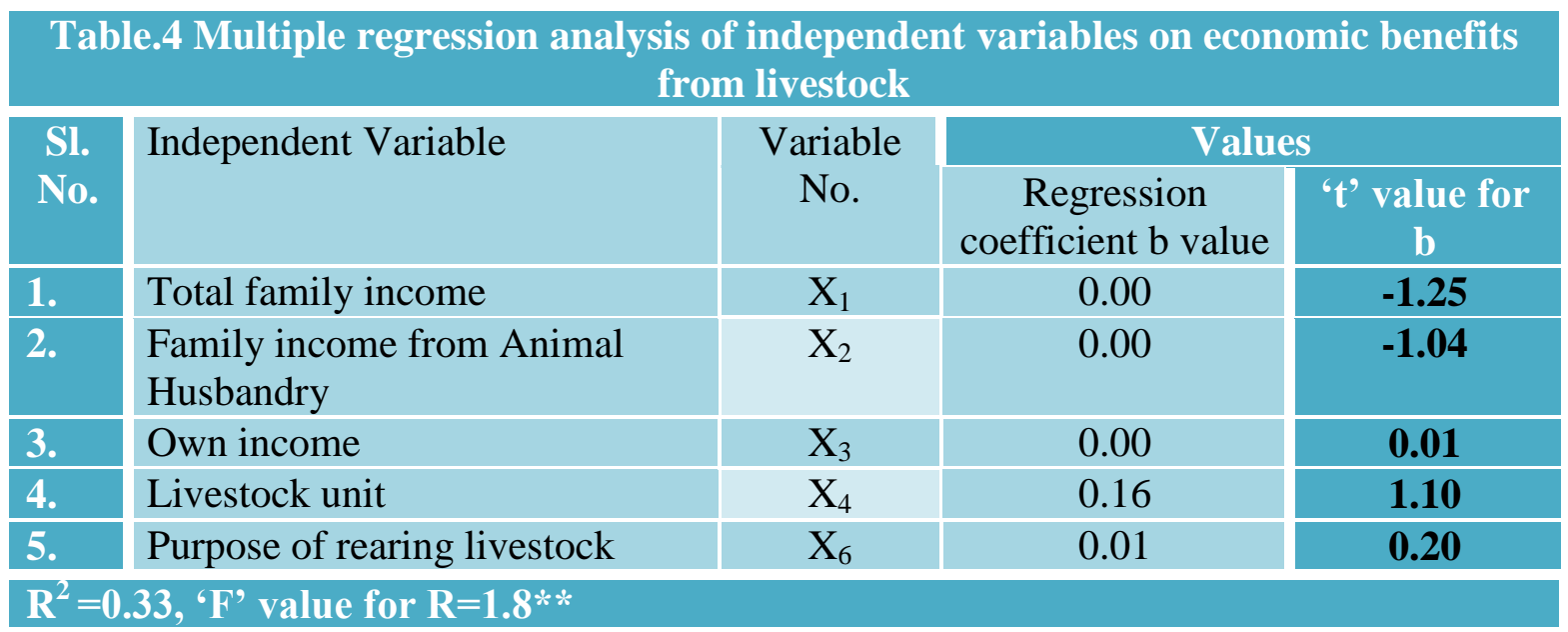

Das (2005) reported that primary purpose of cattle rearing was to perform the agricultural operation for livelihood. Borthakur (2006) stated that majority (55 per cent) of the respondents were rearing poultry for only single reason i.e., either for handsome income or secondary income or for employment opportunity.

Shadab (2015) stated that majority of the respondents reared pigs for the purpose such as 'to recycle the waste food' (100 per cent), to have additional income (99.00 per cent), as a mark of insurance ( 97.00 per cent), because of better profit in short time (96.00 per cent).
Regarding economic benefit obtained by the farmer it could be seen from the Table 2 that the maximum of Rs. 30,000/- per year was obtained by the farmers from buffaloes against lifetime expenditure of Rs. 1,500/- per animal. It was followed by cattle heads with an income of Rs. 4,000/- per head per year against lifetime expenditure Rs. 1,200/- per animal. In case of sheep, goat and poultry chicken and ducks were Rs. 1,000/-, Rs. 1,000/-, Rs. 300/- and Rs. 300/- against lifetime rearing expenditure @ Rs. 400/-, Rs. 400/-, Rs. 100 and Rs. 80/- per animal respectively. Similar findings was reported by Talukdar (2012) where income from livestock 
was found to be Rs. 1,288/- to Rs. 53,588/annually. Baruah (2013) reported the mean income from animal husbandry of the respondents in the North Bank, South Bank of Brahmaputra River in Dhubri District to be Rs.24,660/- to Rs.51,700/- annually. Das (2015) observed that majority of the respondents had medium annual income (Rs.1760.04/- to Rs.27839.95/-) from livestock, whereas 19 per cent and 5 per cent of them had high (above Rs.27839.95/-) and low (below Rs.1760.04/-) annual family income from livestock.

From the Table 3 it is evident that 64.81 per cent of farmers had low (Rs. 15,874/- and lower) annual family income from animal husbandry followed by high (Rs. 21,606/- and above) and medium (Rs.15,873/- to Rs. 21,605/-) annual income levels from animal husbandry at 20.39 and 14.81 per cent respectively. The mean, S.D. and range were Rs.18,740.74/-, +2,865.77 and Rs. 1,500/- to Rs. 2,70,000/- respectively.

As indicated in Table 4, the variables viz., total family income, family income from Animal Husbandry, own income, livestock unit, purpose of rearing livestock did not contribute significantly to economic benefit from livestock. The co-efficient of multiple determination $\left(\mathrm{R}^{2}\right)$ with these independent variables could explain 33 per cent variation in the economic benefit. The ' $F$ ' value for $R$ $\left(1.8^{* *}, \mathrm{P}<0.01\right)$ in case of livestock farmers was found to be highly significant.

In conclusion it can be said that though the purposes of livestock rearing varied to a great extent in the Indo-Bangladesh border areas of Assam, the economic motivation was the main purpose of livestock rearing which could earn the farmers an extra amount along with agriculture. On the other hand as the farmers were dependent on agriculture, rearing of livestock like cattle and buffalo for economic gain and also necessary to carry out the activities like ploughing, carrying bullock cart etc.

\section{References}

Baruah, Sabitri (2013) Differential Animal Husbandry Patterns AMONG Farmers of North and South Bank of Brahmaputra River in Dhubri District. An M.V.Sc Thesis (Unpublished), College of Veterinary Science, Assam Agricultural University, Khanapara, Guwahati-781022, Assam.

Borthakur, B. (2006). A study on the traits of poultry farmers and their effect on their livelihood in Dibrugarh District of Assam. An M.V.Sc. Thesis (unpublished), Assam Agricultural UniversityGuwahati-781022, Assam.

Bujarbaruah, K. M., Nanda, S.N. and Bhusa, B. (1995). Status paper on Livestock Production in NEH Region. ICAR Research Complex for NEH Region, Barapani, Meghalaya.

Das, Bhaswati (2015) Livelihood Diversification options of Farmers and their constraints in Dimoria Develpoment Block of Assam. An M.V.Sc Thesis (un published), College of Veterinary Science, Assam Agricultural University, Khanapara, Guwahati-781022, Assam.

Das, S.K. (2005). Study on Livestock and Livelihood of Rural Inhabitants in Sundarbans Region of West Bengal. Ph. D. Thesis, Deemed University, IVRI, Izatnagar, UP.

Devendra, C. and Chantalakhana, C. (2002). Animals, poor people and food insecurity: Opportunity for improved livelihoods through efficient natural resources management. Outlook on Agriculture, 31(3): 161-175.

Shadab, Frankinstar (2015) Government Sponsored Piggery Development in 
Meghalaya. An M.V.Sc Thesis, College of Veterinary Science, Assam Agricultural University, Khanapara, Guwahati-781022, Assam.

Talukdar, Jupi (2012) Status of Health, Empowerment and Animal Husbandry related to Rural Women. An M.V.Sc Thesis (unpublished), Assam Agricultural University, College of Veterinary Science, Khanapara, Guwahati-781022, Assam.

\section{How to cite this article:}

Liakot Hussain, K.K. Saharia, L. Bora, I.U. Sheikh, D.C. Mili, Sanghamitra Kalita and Payeng, S. 2018. Purpose of Livestock Rearing and Economic Benefit Gained by the Farmers of IndoBangladesh Border Areas of Dhubri District of Assam, india. Int.J.Curr.Microbiol.App.Sci. 7(06): 673-678. doi: https://doi.org/10.20546/ijcmas.2018.706.078 